\title{
ON THE MORPHOLOGY OF THE FEMALE FLOWER OF GNETUM.
}

\author{
By H. H. W. Pearson, Sc.D., F.R.S.
}

\section{(With Plate XVIII.)}

Recent investigations seemed to the writer to furnish support for the view that the female flower and the "spike" of Gnetum are modifications of the same primitive structure-that " the primordium which normally develops into a female flower may, under certain cireumstances, produce a normal cone" (i.e. spike).* This conclusion rested upon evidence which may be briefly reviewed as follows:

(1) The spike is frequently functionally bisexual. + This is regarded as 2 more primitive condition than that of either of the three forms of more common occurrence.

(2) The spike of G. Buchholzianum, normally with seven to nine nodes, may contain as few as two.t There is evidence that the nodes are not laid down in acropetal succession.

(3) A terminal flower oceurs very commonly on both male and female spikes.

(4) Abnormal flowers occasionally show an accessory envelope, the outermost subtending a bud.**

(5) In its general features, the vascular supply to the axis of the female nower resembles that to the axis of the spike.t†

(6) Small vascular complexes found by Miss Berridge in the axis of the

* Pearson, 1915, C, p. 161.

† Pearson, 1915, B, p. 312; 1915, C, p. 156.

$\ddagger$ Pearson, 1912, p. 614.

$\S$ Pearson, 1915, C, p. 158.

|f Strasburger, 1872, p. 158; Pearson, 1915, C, p. 159.

I Pearson, $1915, \mathrm{~B}, \mathrm{p} .312$.

** Loc. cit., pl. 31 , fig. 3.

t+ Pearson, 1915, O, p. 161. 
young seed of G. Gnemon were provisionally interpreted as vestiges of the bundle supply of an aborted ring of male flowers. *

(7) In an injured spike, one of the female flowers of the nodal ring was replaced by a spike.t

Evidence of a more convincing character supporting the same conclusion is furnished by an abnormal female flower of a Gnetum identified as G. scandens, described by MM. Lignier and Tison. + This flower possessed four envelopes. $§$ A transverse section shows in addition a group of normal

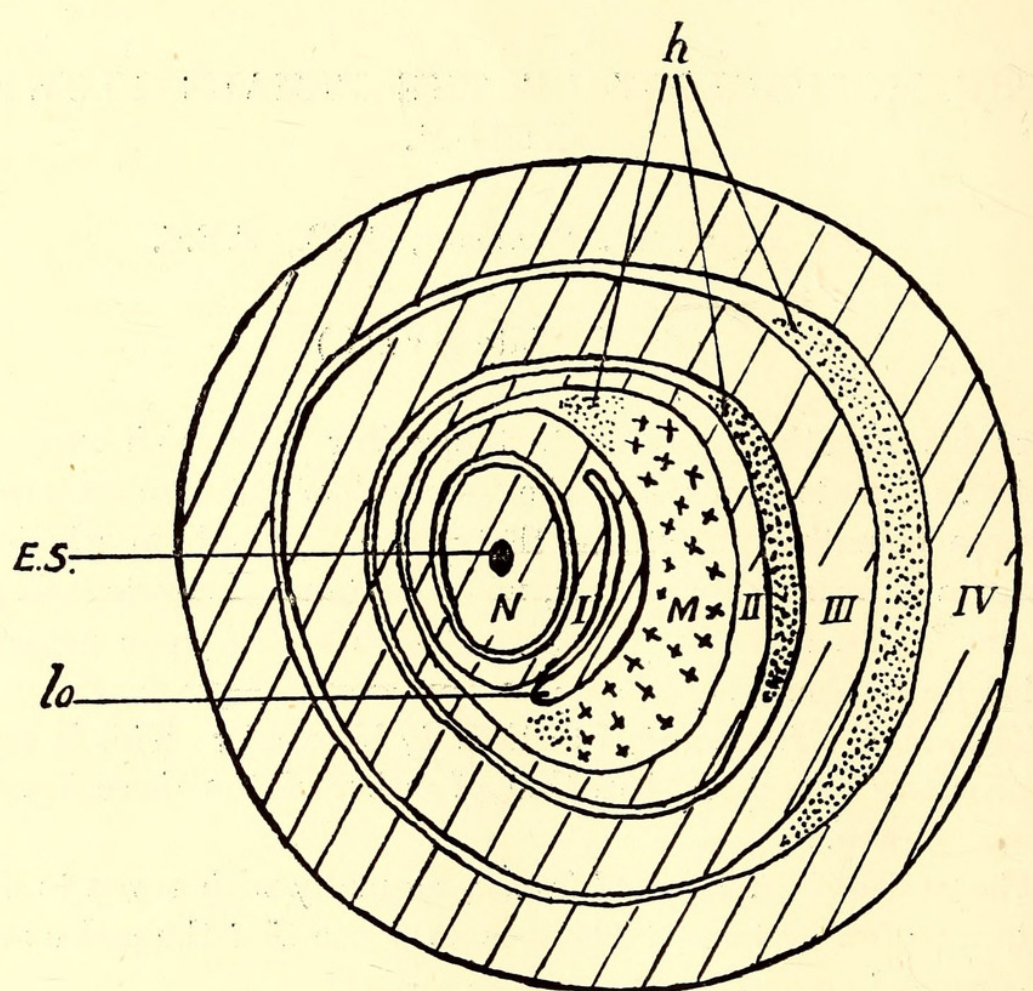

Diagrammatic transverse section of an abnormal female flower of $G$. scandess (after Lignier and Tison). $E . S$. = embryo sac ; $N=$ nucellus ; $I, I I, I I I, I V=$ successive envelopes; $l_{0}=$ lateral lobe of envelope I; $\boldsymbol{M}=$ male flowers ; $h=$ hairs.

male flowers $(M)$ with hairs $(h)$ of the usual type between envelopes I-II; and groups of similar hairs, without flowers, between envelopes II-III and III-IV. Envelope $I$ is without vascular supply; it terminates above in a

* Berridge, 1912, p. 990. This interpretation is not accepted by Lignier and Tison (1913, p. 69).

† Pearson, loc. cit., pl. 25, fig. 7.

\$ Lignier and Tison, 1913. I am indebted to the courtesy of the authors for the only copy of this paper available here. Of the date of its arrival I have no record. I do not doubt that it was in my possession when my own paper $(1915, \mathrm{C})$ was in preparation. I regret that I have completely overlooked it until now (April, 1916).

$\S C f . \S 4$ above. 
normal micropylar tube; it bears a curious leaf-like lobe $\left(l_{o}\right)$. Envelope II is similar in structure to $I$ except that it contains very slender vascular traces. Nos. III and IV are much thicker, and in structure more differentiated than I and II; they are well supplied with small vascular bundles.

The authors, who are on the whole disinclined to attach importance to abnormal structures as evidence in morphological inquiry, ${ }^{*}$ consider that this particular abnormality "offre justement toutes les apparences d'un rétour ancestral." †

Their conclusions are :

(1) The whole structure (nucellus +4 envelopes +3 axillary groups) represents a single node of the inflorescence axis, bearing a cupule and an axillary ovule.§

(2) The cupule (envelope IV) is applied against the surface of the ovule $\S$ and has become a supplementary envelope.

(3) The second envelope of the ovule $\S$ subtends an axillary group of normal male flowers.

(4) Probably the normal female flower of Gnetum (i.e. ovule with 3 envelopes) really represents a simple, perhaps compound, axis provided with 2 nodal cupules (envelopes II and III). This axis is terminated by a "plurilocular" ovary (envelope I) in the interior of which is found, as in Welwitschia, a single ovule basilar, orthotropous, erect, and naked.

(5) This pseudo-ovule $\S$ of Gnetum seems therefore to be comparable with the male flower of Welwitschia, the ovary (envelope I) and its nucellus being almost identical in the two genera.

The two external envelopes (II and III) of Gnetum correspond to the two lower whorls ("perianth") of Welwitschia.

The staminal whorl of Welwitschia (winged envelope of the female flower) has completely disappeared from Gnetum.

(6) In spite of its position immediately outside the ovary (envelope I), it does not seem that the group of male flowers (Text-fig., $M$ ) can be considered as a reversion to an ancestral organisation from which the androecium of Welwitschia is derived.

These conclusions demand careful consideration. We may note in the first place that the authors regard the female flower ("ovule" of §1) as being in the axil of the fourth envelope, the cupule. This seems to complicate the structure quite unnecessarily, for there is no direct evidence in favour of its axillary character. A normal female flower very frequently

* Lignier and Tison, 1912, p. 165, footnote.

+ Lignier and Tison, 1913, p. 70.

$\ddagger$ Loc. cit., pp. 71, 72.

$\S$ This "ovule" is the "pseudo-ovule" of $\S 5$; i.e. the female flower in the ordinary sense. In $\S 4$ the term "ovule" is applied to the naked nucellus. 
terminates the axis of the female, as of the male spike.* The barren tip of the spike axis sometimes shows clear indications that it consists of a cupule fused with the true axis, $\dagger$ just as in the lower nodes the cupule and the axis sometimes remain concrescent. + The subapical cupule may therefore surround, even be concrescent with, a barren axis-tip; it does very frequently surround the base of a truly terminal flower. Therefore the simplest explanation of the cupule (envelope IV) described by MM. Lignier and Tison is that it is situated on the axis which bears the upper envelopes, i.e. the axis of the flower is the direct prolongation of the axis of the spike. The marked peculiarity of this cupule (envelope IV) is that it has assumed the form of a supplementary envelope, as stated in conclusion 2.

The presence of a group of male flowers and hairs above the insertion of envelope II and of a group of hairs only in a similar position with regard to envelope III, seems to establish the first part of conclusion 4 . Now for the first time we appear to be on quite safe ground in regarding the two outer envelopes of the complete (the single outer envelope of the incomplete) female flower of Gnetum as leaf-pairs homologous with the cupules of the spike.

Consideration of the second part of conclusion 4 may be deferred for the moment.

Conclusions 5 and 6 are theoretically of great interest. For the sake of comparison with Table 3 the former may be expressed as follows :

\section{TABLE 1.}

\begin{tabular}{|c|c|c|}
\hline W & & Gnetum + \\
\hline ucellus & $=$ & nucellus. \\
\hline $\begin{array}{l}\text { Envelope I } \\
\text { Androcium }\end{array}$ & $=$ & $\begin{array}{l}\text { envelope I ( = "plurilocular" ovary). } \\
\text { not present. }\end{array}$ \\
\hline $\begin{array}{l}\text { aner perianth } \\
\text { uter perianth }\end{array}$ & $\begin{array}{l}= \\
=\end{array}$ & $\left.\begin{array}{l}\text { envelope II } \\
\text { envelope III }\end{array}\right\}=$ (cupules of Gnetum spike) \\
\hline
\end{tabular}

There is undoubtedly much to be said for this comparison; but however great the probability of this or any other comparison between the flowers of Gnetum and Welwitschia, the facts needed to establish it are not at present available. Apart from the identification of the innermost envelope as an ovary, which is considered below, perhaps the point which most invites: discussion is the treatment of the androecium. MM. Lignier and Tison were obviously forced to consider the possibility that the group of male flowers standing above envelope II in their abnormal flower of Gnetum, was phylogenetically derived from the same primitive structure which has given rise to the androecial whorl of Welwitschia. They have decided against this

* Strasburger, 1872, p. 158 ; Pearson, 1915 C, p. 159.

+ Caporn, 1916.

$\ddagger$ Pearson, loc. cit., fig. 8 . 
view (conclusion 6), and their decision is no doubt justified by the evidence available. But it is possible that a closer acquaintance than we yet possess with the male flower of Ephedra and Gnetum will lead to a modification of the current views of its morphology.*,

None of MM. Lignier and Tison's conclusions has such far-reaching effects as that contained in the second half of No. 4-viz. that the innermost envelope is a plurilocular ovary containing a single ovule.

The somewhat diverse views held as to the natural position of the Gnetales $\uparrow$ at least agree in placing the group in the vicinity of the top of the Gymnosperms and the bottom of the Angiosperms. Parlatore's conclusion $\ddagger$ that it is an "Ordo naturalis inter Coniferas et Casuarinaceas fere medius" is a particular rendering of the current view. More recent investigators have tended rather to emphasise the Angiosperm characters, particularly of Gnetum and Welwitschia, and some have gone so far as to include the whole group among the Angiosperms.§

The identification of the sporophyll would clearly constitute a fact of the first importance in the inquiry as to the relationships of the group. This is attended with great difficulty, for the ovule is apparently not borne on a leaf-structure of any kind; its position and internal structure indicate that the nucellus is a simple prolongation of the floral axis. The search for the homologue of the carpel has been so vigorous that every structure immediately accessory to the Gnetalean ovule has, at one time or another, been recognised as a carpel or a number of concrescent carpels. Each of these diverse views commands some support, but none appears to be free from some vital objection; they are tabulated below (Table 2).

In 1908 Prof. Lignier \| announced the opinion that the Gnetalean ovule, reduced to a naked nucellus, stands erect at the bottom of an ovary, and that the natural position of the group is among the Angiosperms, near the base of the Apetalae. In a reprint of this paper, published in 1911, the Gnetales are regarded as "plus elevées en organisation que je ne le croyais alors (1908), ce sont de véritables angiospermes à organes floraux condensés et réduits." $ণ$

This view of the inner envelope is supported by most careful study of the floral organisation of Welwitschia,** the general conclusions from which were announced a year earlier. $\dagger^{\dagger}$ In the latter paper, $+\dagger$ the flowers of the three genera are referred to a common type consisting of an axis bearing: four whorls of appendages and a naked ovule which "semble prolonger

* $C f$. Pearson, 1915, C.

$\dagger$ Arber and Parkin, 1908, pp. 492-495.

$\ddagger$ Parlatore, 1868, p. 348 .

$\S$ Hallier, 1905, etc.

|| Lignier, 1908.

T. Idem, 1911, p. 61.

** Lignier and Tison, 1912 . $\quad$ † Idem, 1911, A. 
TABLE 2.

\begin{tabular}{|c|c|c|c|}
\hline Carpel or carpels. & $\begin{array}{l}\text { Number of } \\
\text { carpels. }\end{array}$ & Genus. & Author. \\
\hline Bract. . . . & 1 & Welwitschia $q$ & $\begin{array}{l}\text { Pearson, } 1909 \text {; Sykes, } \\
1910 .\end{array}$ \\
\hline $\begin{array}{l}\text { Outermost of } 3 \text { ovular } \\
\text { envelopes }\end{array}$ & 2 & $\begin{array}{l}\text { Gnetum (complete } \uparrow) \\
\text { (Ephedra } \uparrow\end{array}$ & $\begin{array}{l}\text { Blume, 1834 ; Strasbur- } \\
\text { ger, 1872.* } \\
\text { Blume, 1834 ; Van }\end{array}$ \\
\hline $\begin{array}{l}\text { Outer of } 2 \text { ovular } \\
\text { envelopes }\end{array}$ & 2 & $\left\{\begin{array}{l}\text { Gnetum (incomplete } \\
\text { }) \\
\text { Welwitschia } q\end{array}\right.$ & $\begin{array}{l}\text { Tieghem, 1869, 1891 } \\
\text { Strasburger, 1872.* }\end{array}$ \\
\hline $\begin{array}{l}\text { Innermost ovular en- } \\
\text { velope of } q \text { flower }\end{array}$ & 2 or 4 & $\left\{\begin{array}{l}\text { Ephedra } \\
\text { Gnetum } \\
\text { Welwitschia }\end{array}\right.$ & $\begin{array}{c}\text { Beccari, } 1877 \text {; Lignier, } \\
1908 \text {; Lignier and } \\
\text { Tison, 1911 B, 1912. }\end{array}$ \\
\hline $\begin{array}{l}\text { Single ovular envelope } \\
\text { of } \delta \text { flower }\end{array}$ & 2 or 4 & Welwitschia & $\begin{array}{l}\text { Strasburger, } 1872+\text {; } \\
\text { Macnab, 1873; Lig- } \\
\text { nier, 1908; Lignier } \\
\text { and Tison, 1911, } 1912 .\end{array}$ \\
\hline $\begin{array}{l}\text { Completely aborted } \\
\text { ovuliferous scale }\end{array}$ & 1 & $\begin{array}{l}\text { Ephedra } q \\
\text { Gnetum } q \\
\text { Welwitschia o \& } q\end{array}$ & Lignier, 1903. \\
\hline
\end{tabular}

\section{TABLE 3.}

\begin{tabular}{|c|c|c|c|c|c|c|c|}
\hline \multirow{2}{*}{ Whorl. } & \multirow{2}{*}{ Type $\left(\begin{array}{c}\hat{\phi} \\
+\end{array}\right)}$. & \multicolumn{2}{|c|}{ Welwitschia. } & \multirow{2}{*}{$\begin{array}{c}\text { Ephedra, } \\
\text { Gnetum } \\
(\delta) .\end{array}$} & \multirow{2}{*}{$\begin{array}{c}\text { Ephedra } \\
\text { ( }(q) .\end{array}$} & \multicolumn{2}{|c|}{ Gnetum ( $q$ ). } \\
\hline & & (o) & (q). & & & Complete. & $\begin{array}{l}\text { Incom- } \\
\text { plete. }\end{array}$ \\
\hline 1 & $\begin{array}{c}\text { “Ovaire } \\
\text { fermé,” } \\
\text { with style } \\
\text { and stigma. } \\
\text { Ovule fertile }\end{array}$ & $\begin{array}{l}\text { 2-4-carpel- } \\
\text { lary ovary, } \\
\text { with style } \\
\text { and stigma. } \\
\text { Ovule sterile }\end{array}$ & \begin{tabular}{|} 
2-4-carpel- \\
lary ovary, \\
without \\
stigma. \\
Ovule fertile
\end{tabular} & Notrace & $\begin{array}{c}\text { 3-2-car- } \\
\text { pellary } \\
\text { ovary, } \\
\text { without } \\
\text { stigma }\end{array}$ & $\begin{array}{l}\text { Ovary } \\
\text { without } \\
\text { stigma }\end{array}$ & $\begin{array}{l}\text { Ovary } \\
\text { without } \\
\text { stigma. }\end{array}$ \\
\hline 2 & Androecium & Androecium & $\begin{array}{l}\text { Winged } \\
\text { envelope }\end{array}$ & $\begin{array}{c}\text { Androe- } \\
\text { cium }\end{array}$ & $\begin{array}{l}\text { Enve- } \\
\text { lope }\end{array}$ & $\begin{array}{l}\text { Enve- } \\
\text { lope } \ddagger\end{array}$ & ${ }_{\text {rested. }}^{\mathrm{Ar}-}$ \\
\hline 3 & $\begin{array}{c}\text { 2-membered } \\
\text { perianth }\end{array}$ & $\begin{array}{l}\text { 2-membered } \\
\text { perianth }\end{array}$ & No trace & $\begin{array}{l}2 \text {-mem- } \\
\text { bered } \\
\text { perianth }\end{array}$ & No trace & $\begin{array}{l}\text { Peri- } \\
\text { anth }\end{array}$ & $\begin{array}{l}\text { Peri- } \\
\text { anth. }\end{array}$ \\
\hline 4 & $\begin{array}{c}\text { 2-membered } \\
\text { perianth }\end{array}$ & $\begin{array}{c}2 \cdot \text { membered } \\
\text { perianth }\end{array}$ & $\begin{array}{c}\text { Very rarely } \\
\text { present. } \\
\text { Otherwise } \\
1-2 \text { pairs } \\
\text { of reduced } \\
\text { traces in axis }\end{array}$ & No trace & No trace & $\begin{array}{c}\text { No } \\
\text { trace } \pm\end{array}$ & $\begin{array}{c}\text { No } \\
\text { trace. }\end{array}$ \\
\hline Column & 1 & 2 & 3 & 4 & 5 & 6 & 7 \\
\hline
\end{tabular}

* Strasburger abandoned these opinions later, and regarded the envelopes concerned as integuments (Strasburger, 1879, p. 96). Incidentally Strasburger (loc. cit., p. 133) states that " die auf das ovulum reducirten weiblichen Blüthen der Gnetaceen scheinen mir nicht mit den männlichen Blüthen dieser Pflanzen vergleichbar zu sein" $(c f$. Pearson, 1915, C).

+ In 1879 Strasburger (p. 133) abandons this view also, and speaks of the remarkable stigma-like expansion of the free edge of this envelope as "eine Anpassung des Integumentrandes an den Insectbesuch.”

+ These views are now abandoned by the authors. See Table 1 and Lignier and 'Tison, 1913.

$\S$ Vide Lignier and Tison, 1912, p. 130, fig. 24. 
l'axe floral, mais est très probablement de nature foliare." * This type is now most nearly represented by the male flower of Welwitschia. All these whorls are present only in the male flower of Welwitschia; in other cases one or more are entirely missing, or their former presence is indicated only by peculiarities of the vaseular system. The authors' comparison* is here reduced to tabular form (Table 3 ).

The comparisons contained in column 4 of this table have been recently discussed elsewhere. $\dagger$ Those of columns 6 and 7, except as regards whorl 1 , have now been modified by the authors. + It should be noted, however, that the androecium (whorl 2) of the hypothetical type still appears in three different forms - viz. an androecium, a winged envelope and an envelope without wings (Ephedra $q$ ) - the two extremes of these occurring in the same species. This in itself would be remarkable; but evidence that will either establish or overthrow the suggested homology is lacking. It has been stated more than once that evidence in support of this same comparison was advanced by Bertrand.§. This is not strictly correct, for he did not distinguish the male from the female flowers. In his view the staminal tube of the male flower and the winged envelope of the female were two stages in the ontogeny of one and the same structure.\| $\mathrm{He}$ says, for example, that the winged envelope "résulte de la transformation" of the staminal tube. This transformation is thus described: "Sitôt après la pollinisation, les anthères tombent, l'orifice du tube staminal se rétrécit, et ses bords latéraux s'étendent pour former deux grandes ailes marginales." Bertrand's contribution to the discussion is therefore limited to emphasising the fact that these two envelopes possess common characters, by regarding them as identical. $\uparrow$

In this connection it may also be noted that MM. Lignier and Tison imply that Bertrand considered this winged envelope to be an ovary.** On the contrary, he combats this view, previously propounded by Macnab, $+\dagger$

* Idem, 1911, A, p. 1.

+ Pearson, 1915, C.

\pm See Table 1 .

$\S$ Pearson, 1909, p. 336 ; Lignier and Tison, 1912, p. 67.

|| Vide Bertrand, 1878, pp. 63, 82, 86, 89 ; pl. 9, figs. 7, 8, 9.

T That Bertrand should have so misinterpreted the relations of the Welwitschia flowers is remarkable, for, although he does not cite Hooker (1863), he refers to Strasburger (1872) and to Macnab (1873). With regard to the latter he refuses to admit the accuracy of his figures and says (p. 65): “Entre les fleurs hermaphrodites et les fleurs femelles, je n'ai trouvé de différences que dans l'absence des anthères au tube staminal de la fleur femelle." It is probable that his material was scanty. . His earlier account of the anatomy of Welwitschia was based upon the study of a single dried specimen received from Decaisne (Bertrand, 1874, p. 8).

** Lignier and Tison, loc. cit.

†† Macnab, 1873. 
with some emphasis. He says, indeed, that its structure does not differ from that of an ovary, but he proceeds : " Est-ce pour cela un ovaire? Personne je crois, ne le soutiendra sérieusement."*

We may now consider the first whorl (Table 3), which is absent from the male flowers of Ephedra and Gnetum, but elsewhere appears as an ovary. This identification is based upon the results of the authors' very detailed study of Welwitschia. $\dagger$ The evidence is mainly anatomical; the form of this envelope terminating in "a long style and a stigma" also has weight. + The authors even go so far as to describe this envelope as " un ovaire clos," + a description which is not justified by the structure.

The anatomical evidence is furnished by four small vascular bundles, which, in the male flower, pass into the base of the ovular envelope. Of these the two larger lie in the median, the two smaller in the tangential plane. The envelope is therefore regarded as an ovary formed by two concrescent pairs of carpels.§ With regard to these bundles on which such important conclusions are based, it may be noted that (1) at the level at which the envelope becomes free from the nucellus the two stronger are already extremely reduced $\| ;(2)$ their number doas not appear to be constant ; (3) they do not always penetrate the base of the envelope.**

For the inner envelope of the female flower of Welwitschia the evidence is more slender. This envelope admittedly arises as an equal ring from the base of the nucellus, ++ already well advanced. Later the limb becomes lobed, the lobing being regarded as of no morphological significance.+女 The interpretation of the anatomy of this flower is " horriblement difficile." §§ In one case the anterior bundles of the floral axis "persistent même suffisamment pour arriver à pénétrer jusque dans la base du tegument interne (ovaire).' || I In others no bundles enter the free region of the envelope. $\uparrow \uparrow$ The authors regard this envelope as homologous with the ovular envelope of the male flower; as an ovary of four carpels of which the lower pair are

* Bertrand. loc. cit., p. 82. See also p. 65.

+ Lignier and Tison, 1912.

$\ddagger$ Loc. cit., pp. 100, 171.

$\S$ Loc. cit., p. 112.

|| Lignier and Tison, 1912, fig. 10.

T Sykes, 1910, p. 189.

** Bertrand, 1878, p. 64; Sykes, loc. cit., p. 187.

t† Lignier and Tison, 1912, p. 130: Pearson, 1906, fig. $20 \mathrm{~A}$.

It Lignier and Tison, loc. cit. The authors here state that this inner envelope is lightly lobed in the tangential plane. This statement is supported by a reference to their figure (C, fig. 24), in which the outer envelope (iii) is thus lobed. The inner envelope which is under discussion is not shown in this figure.

$\S \S$ Lignier and Tison, 1912, p. 138.

III Loc. eit., p. 144.

ๆ Loc. cit., p. 141; Sykes, 1910, pp. 198, 199. 
more strongly reduced. In both cases the ovary contains a single naked ovule which is " probably of foliar origin." *

MM. Lignier and Tison's opinion that the structure of the inner envelope in the three cases considered above is most naturally explained on the assumption that it has undergone strong reduction may be correct. But even if we go so far as to assume that in a more primitive state each had a strongly developed vascular system, they are not therefore carpellary. The utmost that such a fact could be held to prove would be that this envelope represents one or more leaf structures-a conclusion which many investigators have already adopted. But in view of the known structure of the ovular envelope in the Cycads and in a number of the lower Angiosperms, $\uparrow$ the mere fact that it is vascularised is not sufficient to establish the conclusion that it is foliar; still less does it prove it to be the homologue of an ovary; and if it be foliar it is not therefore impossible that it may be still an integument.

With regard to the external form of this envelope in the male flower of Welwitschia, Hooker, who regarded it as an integument, comments upon its resemblance to a carpel with style and stigma $\ddagger$ and "speculates" on the possibility of its form being inherited from an existing or extinct race of plants in which "the office of the stigma of the carpellary leaf was performed by a stigmatic dilatation of the ovular coat itself." Strasburger, for whom it was at first $\S$ a carpel, later an integument,\| also clearly regarded it as a stigma which had lost its stigmatic function. Its form and structure so obviously suggest such a function, and incidentally tend to strengthen the morphological comparison with an ovary, that it is well to remember that there is no direct evidence whatever that it has ever functioned as a stigma or that it is a reduced form of a functional stigma. There is, however, good reason to believe that it now performs a function in connection with the attraction of insect visitors. 9 It is possibly an excretory organ**; it is certainly largely responsible for the conspicuous-

* Lignier and Tison, 1912, p. 162.

$\dagger C f$. Hemsley, 1906; Kershaw, 1909, A. B. C.; Benson and Welsford, 1909. MM. Lignier and Tison's position with regard to these cases is not clear. If the ovule is reduced to a nucellus, as appears to be suggested (loc. cit., 1912, p. 161), then the first envelope (integument) of Juglans and Myrica is, by inference, carpellary. Probably the authors do not intend to convey this impression, and, if so, it is not easy to see why the very reduced vascular system in the envelope of Welwitschia or Gnetum should mean so much more than the strongly developed system of Juglans or Myrica.

$\ddagger$ Hooker f., 1863, p. 24.

§ Strasburger, 1872, p. 153.

II Strasburger, 1879, p. 133.

T Strasburger, 1872, p. 272.

** Pearson, 1906, p. 274; Lignier and Tison, 1912, p. 122 ; but see Church, 1914, p. 135. 
ness of the open flower. Its form may just as well be an adaptation to the despatch as to the receipt of the pollen. In the former we believe that it plays a not unimportant part; with the latter we know that it has at present no concern, and there is no sufficient reason for supposing that it ever has been concerned. If, on the other hand, this stigma-like structure had ever in its history played the part of a true stigma, it would be surprising that it should have disappeared so entirely from the envelope of the female flower which does function as a pollen-receiver, and in an exceedingly efficient manner.*

Further, it is well established, in each of the three genera, that the nucellus precedes this envelope in ontogeny. In the female flower of Welwitschia, the megaspore mother-cell is constituted before the first signs of the inner envelope are apparent. $\uparrow$ The relations are similar in Ephedra and Gnetum. + In all three the megaspore on germination grows down into the axis to a point far below the level at which the envelope becomes free from: the nucellus.§ $\|$

These relations are not characteristic of carpels and ovules; they do commonly obtain between integuments and nucelli, more especially amongthe Gymnosperms. It is perhaps within the range of possibility that an Angiosperm ovary should become so reduced and retarded in development as to simulate so remarkably a Gymnosperm integument, but it seems so. improbable that strong evidence would be needed to show that its observed characters are so entirely deceptive; and no such evidence is yet forthcoming. $\uparrow$

If, for instance, it could be shown that the nucellus is not a terminal structure but is inserted on the envelope (which in fact arises from it), this would go far to reduce the significance of its resemblance to an integument.

The question of the cauline or foliar position of the ovule has been much discussed, particularly within recent years. If it is truly cauline the difficulty of comparing the Gnetalean "flower" with corresponding structures in both the Gymnosperms and the Angiosperms is, in the present state of our.

* Pearson, 1909, pl. 23, fig. 11.

$\uparrow$ Pearson, 1906, pl. 19, figs. 20, 20 A.

† Strasburger, 1872, Taf. xv, figs. 45, 46; Karsten, 1893, fig. 29.

Thoday and Berridge, 1912, text-fig. 11; Thoday, 1911, text-fig. 9; Sykes, 1910, diagr. xviii.

|| Schuster (1911) refuses to regard this envelope as an ovary because of the presence of archegonia of the Gymnosperm type. To this Lignier and Tison (1912, p. 171) object that (1) the archegonium is not present in Welwitschia nor in Gnetum; (2) the absence of the archegonium has never been regarded as a necessary character of the Angiosperms. These objections are certainly sound; if the archegonium removes Ephedra from the Angiosperms, the absence of archegonia must equally remove Welwitschia and Gnetum from the Gymnosperms.

ๆ $C f$. Church, 1914, p. 122. 
knowledge, greater than if it can be shown to be foliar. This very fact justifies a demand for clear proof that it is other than it seems.

Most investigators have accepted the facts on their face value and have concluded, or have seen no reason to question the conclusion, that the flower is a bud and that the ovule terminates the floral axis.*

Van Tieghem $\dagger$ appears to have been the first to advance a contrary opinion. At the end of a long paper mainly concerned with the morphology of the flower in the Cycads and the Conifers, he devotes less than two pages. to the Gnetaceae, of which apparently he was able to study only the female flower of Ephedra distachya. He concludes that the outer envelope is the last product of the floral axis; that it represents a single leaf, placed opposite to the subtending bract; that it bears the unitegumented ovule on its ventral face; that its edges are concrescent on the ventral side of the ovule which it encloses save for the apical aperture through which the micropylar tube of the inner envelope protrudes. This outer envelope is then an open carpel (ovuliferous scale) without style or stigma. This view is based entirely upon analogy with the Coniferae and the vascular structure; the development of the parts concerned is not considered. A study of the development shows that this ovary or ovuliferous scale, like the inner envelope, is an outgrowth from the ovule which, according to Van Tieghem, it bears ; further, it arises from two primordia $\ddagger$ and represents two $\S$ or three $\|$ leaves, or from four primordia representing four leaves. If it is sought to extend this hypothesis to Gnetum and Welwitschia, the "ovuliferous scale" is not represented in the male flower of the latter-unless indeed the original inner envelope is concrescent with the nucellus**. or is aborted, †† neither of which suggestions is supported by adequate evidence. In the case of Gnetum, Van Tieghem's hypothesis necessitates the conclusion that the two outer envelopes of the complete female flower of Gnetum have different morphological values, which, in view of more recent evidence, $+\ddagger$ is impossible.

* Ephedva: Eichler, 1863, p. 266; Strasburger, 1872, pp. 80, 83, 87, 235, Taf. xv, fig. 47 ; Bertrand, 1878, p. 65; Jaccard, 1894, p. 13; Arber and Parkin, 1908, pp 497, 504; (cf. also Thoday and Berridge, 1912, pp. 978, 979). Gnetum: Eichler, loc. cit.; Beccari, 1877 ; Bertrand, loc. cit.; Strasburger, 1879, p. 107 ; Lotsy, 1899, p. 64; Arber and Parkin, loc. cit. ; Berridge, 1912,p. 991. Welwitschia: Hooker, 1863, pp. 23, 30 ; Eichler, loc. cit.; Strasburger, 1872, pp. 93, 94; Macnab, 1ъ73, p. 507 ; Bertrand, loc. cit.; Arber and Parkin, loc. cit.; Pearson, 1909, p. 334; Sykes, 1910, p. 194 (but also see pp. 216, $221)$.

$\dagger$ Van Tieghem, 1869, p. 291.

‡ Strasburger, 1872, Taf. xv, fig. 46.

$\S$ Loc. cit., p. 235.

|| Lignier and Tison, 1911, B.

T S Land, 1904, p. 8.

** Sykes, 1910, p. 207.

†† Strasburger, 1872, p. 150.

++ Lignier and Tison, 1913. 
Van Tieghem later modified his opinion, and his ovuliferous scale became a bicarpellary ovary* without style or stigma.

In 1903, Lignier + adopted a modification of Van Tieghem's earlier hypothesis. The second envelope (second and third in the complete $q$ of Gnetum) is a whorl of concrescent bracts. An ovuliferous scale is axillary to one of these bracts ; the unitegumented ovule is inserted on the summit of this scale. The scale, however, is so reduced that there is no visible sign of its presence, and the unitegumented ovule therefore appears to be a direct prolongation of the axis. This hypothesis rests entirely upon a supposed analogy with Taxus, ${ }_{+}^{+}$and there is no direct evidence in support of it. It has since been abandoned by its author in favour of the view discussed above, viz. that the innermost envelope is a pluricarpellary ovary.

Other authors retain an open mind with regard to the cauline or foliar origin of the ovule. Mrs. Thoday states that the female flower of Welwitschia consists of a "short axis terminated by a single ovule" which is enclosed in two envelopes. $\S$ Later, in the same paper, it is suggested that "although the ovules in the male cone and the stamens and aborted ovules in the male cone are now in an axillary position, they may not originally have been cauline." $\|$ The meaning of this suggestion as regards the female flower is that it "represents a sorus which was originally borne on the bract" ; the male flower presents greater difficulty, but "it appears possible" that it also is "derived from a form in which the sporophyll bore several sori." The author states quite distinctly that this is merely a suggestion based on an analogy with the Cycads, just as Van Tieghem's and Lignier's earlier views rested upon analogy with the Coniferae. For none of the three is there any direct evidence.

With regard to Ephedra and Welwitschia still another hypothesis, having a similar end in view, has been advanced. It suggested that the single ovule "now differentiated direct from the plastic apex of the axillary bud" is "the equivalent of more than one ovule, each originally borne on a foliar organ, but now fused together at the apex of an axis"**-in other words, that the apical portion of the ovule-bearing shoot is composed of concrescent leafistructures. This is an interesting speculation suggested by the occasional indications of the fusion of two ovules in Ephedra altissima, + t a phenomenon which is most simply explained on physiological grounds.

* Van Tieghem, 1891 ( fide Lignier, 1903).

† Lignier, 1903.

$\ddagger$ Loc. cit., p. 67 .

Thoday, 1910, p. 194.

\| Loc. cit., p. 221.

Tा Loc. cit., p. 216.

"** Thoday and Berridge, 1912, p. 979.

†† Loc. cit., p. 962. 
The results of these various attempts to find evidence for the foliar insertion of the Gnetalean ovule rather tend to confirm the opinion of those who have adopted the simplest interpretation of the observed facts and have accepted the ovule as truly cauline in position. In any case neither of the hypotheses (1) that the inner ovular envelope is an ovary; (2) that the ovule is foliar in position now or in ancestral types, can be used to support the other. Each of them lacks the evidence necessary to establish it.

In attempting to interpret doubtful structures occurring in the group Gnetales we encounter special difficulties which we are perhaps a little inclined to under-estimate. Of the origin of the group we know nothing. We have good reason to believe that the three existing genera are the remnants of an ancient race once more numerously represented than it is now; even this is open to question, as MM. Lignier and Tison have shown. Their relations to the rest of the Gymnosperms, as to the Angiosperms, are quite obscure; those obtaining between the still living members of the group are but little clearer. While we need not yet despair of finding evidence sufficient to illuminate some, perhaps all, of these obscurities, it cannot be denied that, at the moment, no clear light has been thrown upon any of them.

In the meantime the value of interpretations founded upon analogy with other Gymnosperms, extinct or living, or with the Angiosperms, unless they are adequately supported by internal evidence, is the value of the new lines of investigation which they indicate. Internal evidence has convinced the great majority of those who have studied members of the group that in spite of the appearance in them of certain Angiosperm characters, they are essentially Gymnosperms. The important investigation of the floral structure of Welwitschia which we owe to MM. Lignier and Tison does not appear to unsettle the conclusions * reached by Eichler in 1863-“"Gnetaceae vere sunt Gymnospermae. . . . Illa est gravissima ovulorum dignitas morphologica, quod hand, ut Cycadeis, e carpophyllo enata qualitatem teneant foliaceam, sed axis floralis ipsius summitatem sistant."

If these considerations are allowed to have weight, our knowledge of the morphology of the female flower of Gnetum as extended by MM. Lignier and Tison's latest investigation $\uparrow$ may perhaps be summarised as follows:

(1) The two outer envelopes of the complete, the single outer envelope of the incomplete, female flower are homologous with the cupule of the spike. Here, as in the Angiosperms, sterile reduced leaves exercise a protective function with regard to the megasporangium. This resemblance

* It should, however, be stated here that Professor Lignier, in the letter referred to (p. 8), says: "En ce qui concerne l'interpretation ovaire au lieu de tégument ovulaire, nous avons trouvé de nouveaux arguments (in Ephedra) très différents de ceux offerts par le Welwitschia et qui nous semblent beaucoup plus probants."

† Lignier and Tison, 1913. 
does not appear to involve the conclusion that the "perianth" in the one group is phylogenetically related to that of the other. *

(2) There is no evidence to show that the innermost envelope is phylogenetically related either to the ovary or to the integument of the Angiosperm. It probably consists of a modified leaf pair homologous with the cupule.

(3) The nucellus is the direct prolongation of the axis which bears the envelopes.

(4) The axis of the flower is homologous with the axis of the spike.

(5) The "spike" and the female flower are modifications of the same primitive structure, the character of which is certainly not indicated by any evidence at present available. An obvious suggestion is that it consisted of (1) a terminal nucellus surrounded by a single ovular envelope; (2) a ring of lateral male flowers, below which stood (3) one or more modified leaf pairs.

A comparison of the Gnetum female flower with those of the other genera and with the male flowers of Welwitschia will certainly lead to the conclusion that the ovule (i.e. nucellus + envelope I, vide Plate XVIII) is strictly homologous throughout the group.

The view that the second envelope of the Welwitschia female flower is the equivalent of the whorl of microsporophylls of the male flower is not disproved. On the other hand, there is no convincing evidence in its favour. The same is true for the alternate hypothesis, which neverthless most morphologists will probably prefer, viz. that this envelope (II, Plate XVIII) in Welwitschia and Ephedra is homologous with II (and therefore with III) of the Gnetum flower. The comparison may probably be extended to the two whorls of "perianth" in the male flower of Welwitschia.

If these generalisations represent an approximation to the truth, we must accept the conclusion that these four flowers are modifications of a common primitive type-a conclusion which has never been seriously questioned. Hitherto the only direct evidence for the former existence of such a common type has bean the present existence of the male flower of Welwitschia-presumed to be a reduced condition of a primitively hermaphrodite flower. Tothis we may now add the new knowledge furnished by MM. Lignier and Tison for Gnetum.

A functionally hermaphrodite spike occurs not uncommonly in Gnetum $\dagger$ as well as in Ephedra. $\neq$ The new light now thrown upon the relation bətweวn the flower and the spike in Gnetum compels us to consider whether it does not also provide a new basis for the comparison of the flowers and inflorescences of the group and for tracing their descent from a common type.

* $C f$. Coulter and Chamberlain, 1910; Lignier and Tison, 1912, p. 125.

+ Pearson, 1915, B and C.

$\ddagger$ Wettstein, 1907; Porsch, 1910. 
MM. Lignier and Tison have considered this question, and, for an obvious lack of evidence, have answered it in the negative.*

The chief difficulty is presented by the so-called male flowers of Gnetum and Ephedra. But as long as there exists any doubt as to the correctness of the current interpretation of these sporangiophores and their "perianth," $\uparrow$ the possibility that the hypothetical primitive structure of $\$ 5$ (p. 82) and the reduced hermaphrodite flower of Welwitschia are more nearly related than at present seems possible, cannot be dismissed.

\section{National Botanic Gardens, \\ KirstenBosch, \\ June, 1916.}

Note.-This paper owes its origin to a letter dated December 22nd, 1915, in which the late Professor Lignier discussed the interpretation of the Gnetalean flower adopted by him and his collaborator, M. Tison. The greater part of it was written in the expectation that it would have the benefit of Professor Lignier's criticism. It is completed in a spirit of homage to the memory of a distinguished botanist.

* Lignier and Tison, 1913, p. 72.

† Pearson, 1915, C. 


\section{BIBLIOGRAPHY.}

Arber, E. A. N., \& J. Parkin.

1908. Studies on the Evolution of the Angiosperms. The Relationship of the Angiosperms to the Gnetales. Ann. Bot., xxii, p. 489.

BECCARI, $O$.

1877. Della organogenia dei fioeri-feminei del Gnetum Gnemon, L. Nuov. Giorn. bot. Ital., ix, p. 91.

Benson, M., \& E. J. WeLSFORd.

1909. The Morphology of the Ovule and Female Flower of Juglans regia and of a few allied genera. Ann. Bot., xxiii, p. 623.

BERRIDGE, E. M.

1912. The Structure of the Female Strobilus in Gnetum Gnemon. Ann. Bot., xxvi, p. 987.

Bertrand, C. E.

1874. Anatomie comparée des Tiges et des Feuilles chez les Gnetacées et les Conifères. Ann. d. Sc. Nat. Bot. (5), xx, p. 5.

1878. Étude sur les Teguments séminaux des vegetaux Phanérogames gymnospermes. Loc. cit. (6), vii, p. 61.

BLume, C. L.

1834. De novis quibusdam plantarum familiis expositio, et olim jam expositarum enumeratio. (Translation.) Loc. cit. (2), i, p. 89. (Gneteae, p. 101.)

Caporn, A. St. C.

1916. A Note on the Male Inflorescence of a species of Gnetum from Singapore. Ann. Bol. Herb., ii, p. 15.

Church, A. H.

1914. On the Floral Mechanism of Welwitschia mirabilis (Hooker). Phil. Trans. (B), 205, p. 115.

Covlter, J. M., \& C. J. Chamberlain.

1910. Morphology of Gymnosperms. University of Chicago Press.

EICHLER, A. W.

1863. Excursus morphologicus de Formatione Florum Gymnospermarum. Ann. d. Sc. Nat. (4), xix, p. 257.

Gorber, K.

1905. Organography of Plants. (English Edition.) ii. Clarendon Press.

HALLIER, H.

1905. Provisional Scheme of the Natural (Phylogenetic) System of Flowering Plants. The New Phytologist, iv, p. 151.

Hemslex, W. Botting.

1908. On the Julianiaceae. A New Natural Order of Plants. Phil. Trans. Bot., p. 199.

Hooker, J. D.

1863. On Welwitschia, a new genus of Gnetaceae. Trans. Linn. Soc., xxiv, p. 1 . 
JACCARD, P.

1894. Récherches embryologiques sur l'Ephedra helvetica. Lausanne.

KERSHAW, E. M.

1909. A. Note on the Relationship of the Julianiaceae. Ann. Bot., xxiii., p. 336.

B. The Structure and Development of the Ovule of Myrica Gale. Loc. cit., p. 353 .

C. Further Observations on the Structure of the Ovules of Myricaceae and Allied Groups. Loc. cit., p. 692.

LAND, W. J. G.

Spermatogenesis and Oogenesis in Ephedra trifurca. Bot. Gaz., xxxviii., p. 1.

LigNIER, 0 .

1903. La Fleur des Gnétacées est-elle intermediare entre celle des Gymnospermes et celle des Angiospermes? Bull. Soc. Linn. Norm. (5), vii, p. 55.

1908. Essai sur l’Évolution morphologique du Régne végétal. Assoc. Franc., Congr. de Clermont-Ferrand, Août, 1908.

1911. - (Reprint). Bull. Soc. Linn. Norm. (6), iii, part 2, p. 35.

\& H. Tison.

1911. A. Les Gnétales sont des Angiospermes apétales. C. R. Acad. Sc. Paris, p. 1.

1911. B. La Fleur de l'Ephedra est trimère. Bull. Soc. Bot. Fr. (4), xi, p. 178.

1912. Les Gnétales, leurs fleurs et leur position systematique. Ann.d. Sc. Nat. (9), xvi, p. 55.

1913. L'ovule tritegumenté des Gnetum est probablement un axe d'inflorescence. Bull. Soc. Bot. Fr. (4), xiii, p. 64.

Lotsy, J.

1899. The Grosser Morphology of Production of Gnetum Gnemon, L. Ann. Jard. Bot. Buit., xvi, p. 46.

Macnab, W. R.

1873. On the Development of the Flowers of Welwitschia mirabilis, Hook, fil. Trans. Linn. Soc., xxviii, p. 507.

Parlatore, $\mathrm{P}$.

1868. Gnetaceae. (A. de Candolle, Prodromus, xvi, 2, p. 347.)

Pearson, H. H. W.

1906. Some Observations on Welwitschia mirabilis, Hook, f. Phil. Trans. (B), 198, p. 265.

1909. Further Observations on Welwitschia. Phil. Trans. (B), 200, p. 331.

1912. On the Microsporangium and Microspore of Gnetum, with some notes on the Structure of the Inflorescence. Ann. Bot., xxvi, p. 604.

1915. A. Notes on the Morphology of Certain Structures concerned in Reproduction in the Genus Gnetum (Abstract). Journ. Linn. Soc., xliii, p. 55.

1915. B. - Trans. Linn. Soc. (2), viii, p. 311.

1915. C. A Note on the Inflorescence and Flower of Gnetum. Ann. Bol. Herb., i., p. 152.

Porsch, 0 .

1910. Ephedra campylopoda, C. A. Mey., eine entomophile Gymnosperme. Ber. d. Deutsch. Bot. Ges., xxviii, p. 404.

\section{SchUSTER, J.}

1911. Weltrichia und die Bennettitales, Sw. Vet.-Akad. Handl., xlvi, No. 11. 
STRASBURGRR, E.

1872. Die Coniferen und die Gnetaceen. Jena.

1879. Die Angiospermen und die Gymnospermen. Jena.

SYKhs, M. G.

1910. The Anatomy and Morphology of the Leaves and Inflorescences of Welwitschia mirabilis. Phil. Trans. (B), 201, p. 179.

THоDAт, M. G.

1911. The Female Inflorescence and Ovules of Gnetum africanum, with notes on Gnetum scandens. Ann. Bot., xxv, p. 1101.

\& E. M. BERRIDGE.

1912. The Anatomy and Morphology of the Inflorescences and Flowers of Ephedra. Loc. cit., xxvi., p. 953.

\section{VAN TIEGHEM, $P$.}

1869. Anatomie de la fleur femelle et du fruit des Cycadées, des Conifères et des Gnétacées. Ann. d. Sc. Nat. Bot. (5), x, p. 269.

1892. Traité de Botanique. Ed. 2. Paris.

WhTTSTEIN, R. von.

1907. Uber das Vorkommen zweigeschlechtiger Infloreszenzen bei Ephedra. Fortsch. d. Naturwiss. Ver. Univ. Wien, p. 21. 


\section{EXPLANATION OF PLATE XVIII.}

Diagrammatic longitudinal sections (tangential to axis of the spike) through ${ }^{-}$the Gnetalean female flowers and the ovule and ovular envelope of the male flower of Welwitschia. Only the lower part of the micropylar tube is shown, except in Welwitschia $\delta$, in which its middle portion is omitted.

I, II, III = envelopes in centrifugal order (strong lines = vascular.system).

$\mathbf{A}=$ base of androecial tube in Welwitschia $\delta$.

E.S. = embryo sac.

$\mathrm{N}=$ nucellus.

$\mathrm{S}=$ "stigma" of Welwitschia $\delta$. 


\section{$2 \mathrm{BHL}$ Biodiversity Heritage Library}

Pearson, H H W . 1917. "ON THE MORPHOLOGY OF THE FEMALE FLOWER OF GNETUM." Transactions of the Royal Society of South Africa 6, 69-87. https://doi.org/10.1080/00359191709520175.

View This Item Online: https://www.biodiversitylibrary.org/item/181547

DOI: https://doi.org/10.1080/00359191709520175

Permalink: https://www.biodiversitylibrary.org/partpdf/175568

\section{Holding Institution}

Smithsonian Libraries

\section{Sponsored by}

Biodiversity Heritage Library

\section{Copyright \& Reuse}

Copyright Status: Not in copyright. The BHL knows of no copyright restrictions on this item.

This document was created from content at the Biodiversity Heritage Library, the world's largest open access digital library for biodiversity literature and archives. Visit BHL at https://www.biodiversitylibrary.org. 